\title{
Keir Hardie: Radical, Socialist, Feminist
}

\section{W. Hamish Fraser}

\section{(2) OpenEdition}

1 Journals

Electronic version

URL: http://journals.openedition.org/etudesecossaises/153

DOI: 10.4000/etudesecossaises.153

ISSN: 1969-6337

\section{Publisher}

UGA Éditions/Université Grenoble Alpes

\section{Printed version}

Date of publication: 31 March 2005

Number of pages: 103-115

ISBN: 2-84310-061-5

ISSN: 1240-1439

\section{Electronic reference}

W. Hamish Fraser, « Keir Hardie: Radical, Socialist, Feminist », Études écossaises [Online], 10 | 2005, Online since 31 March 2005, connection on 10 December 2020. URL : http://journals.openedition.org/ etudesecossaises/153; DOI : https://doi.org/10.4000/etudesecossaises.153 


\section{Keir Hardie: Radical, Socialist, Feminist}

When Keir Hardie died in September 1915 one of the strongest tributes came from James Connolly in the Workers'Republic:

By the death of Comrade James Keir Hardie labour has lost one of its most fearless and incorruptible champions, and the world one of its highest minded and purest souls.... James Keir Hardie was to the labour movement a prophetic anticipation of its own possibilities. He was a worker, with all the limitations from which no worker ever completely escapes, and with potentialities and achievements such as few workers aspire after, but of which each worker may be the embodiment... he was a living proof of the truth of the idea that labour could furnish in its own ranks all that was needed to achieve its own emancipation, the proof that labour needed no heaven-sent saviour from the ranks of other classes. He had been denied the ordinary chances of education, he was sent to earn his living at the age of seven, he had to educate himself in the few hours he could snatch from work and sleep, he was blacklisted by the employers as soon as he gave vent to the voice of labour in his district, he had to face unemployment and starvation in his early manhood and when he began to champion politically the rights of his class he found every prostitute journalist in these islands throwing mud at his character, and defaming his associates.

Yet he rose through it all, and above it all, never faltered in the fight, never failed to stand up for truth and justice as he saw it, and as the world will yet see it.

Adjectives like «fearless», «incorruptible», «prophetic», and «high-minded» are the ones which have generally stuck to his reputation. Although, one could argue, that he was conspicuously unsuccessful during his lifetime in persuading Scots and particularly Scottish miners - to abandon their attachment to Liberalism and to support independent Labour - after all, it was in London and Wales that he had to find a parliamentary seat - nonetheless, he seems to embody much that the Scots include in their historical self-image: self-educated, true to his working-class origins, radical in politics and religion, single-minded, unbending and with a deep attachment to his native heath. In folk memory and in the populist discourse of Labour Party rallies he remains the embodiment of the 
ideal leader who, unlike his successors, rejected the political path of compromise and concession. There is little evidence that academic modifications to the myth have done anything to alter that popular reputation.

The biographical outlines are well-enough known. Born in Lanarkshire in 1856, the illegitimate son of Mary Keir, a domestic servant, who married David Hardie, a ship's carpenter. He called himself James Hardie until the 1880s when he adopted Keir. He started work at the age of 8 , with various jobs and when his father went back to sea in the mid 1860s, he went to work as a trapper in the coal pits. Both mother and step-father were free-thinkers, rejecting Christian belief, and were readers of Charles Bradlaugh's secularist National Reformer. Hardie, however, at the age of twenty-one was converted and became a member of the Evangelical Union, a group of churches which challenged the Calvinist notion of election, which still held sway in most Presbyterian churches, with the belief in universal atonement. He joined the growing temperance movement, the Good Templars, which had spread from the United States in the early 1870s, and which Brian Harrison describes as «a pseudo-masonic organization of the most extreme temperance zealots» (Harrison, 1971, p. 241). Throughout the 1870s he was involved in the process of self-education, going to night school, teaching himself shorthand and submitting short pieces for publication to the Glasgow press. In 1879 he played a major part in organising the Lanarkshire Miners'Union and became miners'agent. When the Lanarkshire Union began to crumble he was invited to help form an Ayrshire one, and in 1880 he moved, with his recent wife, to Cumnock, which was to be his family home for the rest of his life.

As well as his union activities he began writing a column in the local weekly paper, and became active in the Liberal Association. He remained a prominent Good Templar and an occasional lay preacher. He helped establish a Scottish Miners' Federation in 1886 and became its secretary, at the same time launching, his own monthly paper, The Miner. He was clearly developing political ambitions and in 1888 put himself forward as a candidate at the by-election in Mid Lanark. When the Liberal Association failed to select him he stood as an independent labour candidate, on what could be seen as a radical, but still Liberal, programme: home rule, nationalisation of land, abolition of the House of Lords, direct local 
veto on public houses. He got a mere 667 votes. He was immediately accused of being in receipt of «Tory gold» to split the Liberal vote. It was an accusation which was to follow him throughout his life, and it was not without justification in these early days, with funding via H.H. Champion from the Tory Democrat, Maltman Barry. Immediately afterwards Hardie, with a group of disenchanted Liberal radicals, formed the Scottish Labour Party - the first party committed to independent labour representation and to socialism. He was quite specific: «Liberalism is one thing, Socialism is quite another, and the new Labour Party is Socialistic » (Hardie, 1927, p. 32). In the next few years he began to become known nationally with speeches at the Trades Union Congress and visits to London, where he came into contact with other socialists. He attended the Marxist International Congress in Paris in 1889 and developed lasting international contacts, while rejecting the possibility of a revolutionary Marxist road to socialism in Britain.

Eventually, in 1892, he was elected as Member of Parliament for South West Ham in London. This is when the first mythical image of Hardie emerges. He was carried to Westminster by a waggonette full of supporters, including one with a trumpet playing the Marseillaise (Davies, 1992, p.16) and with Hardie reputedly wearing a cloth cap - as opposed to the normal parliamentary uniform of the frock coat and top hat. The Liberal Daily Newes claimed that he arrived «with a blare of trumpets» wearing «a tweed cap, which, taken in conjunction with a short jacket, trousers frayed at the heel, a flannel shirt, and no necktie» appalled it (Lowe, 1923, p. 64). To later generations it indicated that he was «impervious to the blandishments of Parliament with its sense of ease and self importance» (Davies, 1992, p. 28). In Parliament he took up the issue of unemployment and miners'causes and generated the occasional Parliamentary scene. Outside, he played a major part in the formation in 1893 of the Independent Labour Party and was its chairman for the next eight years. Despite this, he and all ILP candidates went down to disastrous defeat in 1895 and it looked as if his political career was at an end. He did, however, continue to have a voice in that The Miner had been turned into the weekly Labour Leader large parts of which were written by Hardie himself, under various pen-names. 
Between 1895 and 1900 he worked with great energy and endless travel to persuade the trade unions to back independent labour and he played down the socialism. He wrote,

The unity of the working class is the one thing that matters. That can never be a thing of rapid growth. Abstract theories with them count for very little.... Socialism supplies the vision and a united working class satisfies the senses as a practical method of attaining its realisation. To attain that unity is, and must be, the first object of all who desire Socialism. (Johnson, 1922, p. 4)

Elsewhere he wrote that «a mere abstraction, be it ever so demonstrable scientifically, will never move masses of people» (Hardie, 1927, p. 93). To win over Nonconformist trade unionists socialism had to be presented as an ethical gospel.

The result was the formation in 1900 of the Labour Representation Committee, uniting socialists and trade unionists in a Party committed to evolutionary change. It was under the auspices of the LRC that Hardie was again returned to Parliament in 1900, this time for Merthyr Tydfil in Wales, which he continued to represent until his death in 1915. In this election in the midst of the South African War, he was elected on a pro-Boer stance. According to Michael Holroyd, Hardie «pictured the Boers as pure-living, God-fearing farmers grazing peacefully under the Christ-like guardianship of President Kruger» (Holroyd, 1989, p. 38). On the other hand, like most of the proBoers, he regarded the war as an «evil war of aggression, waged by capitalist imperialists anxious for quick profits on the Rand» (Morgan, 2003, p. 59). When the LRC became the Labour Party in 1906 with 30 MPs, Hardie became leader of the Party in Parliament, but only for about 18 months, during which he was, according to Philip Snowden, «unbusinesslike, unconciliatory and unreliable» (Morgan, 1975, p. 155).

A hectic pattern of propaganda work on top of parliamentary duties took its toll and he had frequent illnesses. After one in 1907 he set off on a world tour causing a great furore when he made sympathetic noises in favour of Indian nationalism. In South Africa, he caused another row by suggesting to white miners that their union be opened up to black workers. Here he was quite consistent since, almost alone in Parliament, he questioned the way in which the rights of the black population were being swept aside in order to conciliate the Boers and persuade them to accept a South African Union (Morgan, 2003, p. 64-65). 
As European tension mounted, Hardie placed a great deal of faith in international working-class action to stop war, supporting the idea of a general strike. In August 1914 this proved a chimera. As he said, most of his former associates turned out to be «poor slaves who imagined themselves Socialists until the touchstone of war found them out and exposed them for what they are» (Hughes, 1931, p. xiii). His death in September 1915 was often reputed to be due to despair at the failure of the international working class. Tom Johnston's Forward declared, «Hardie has died of a broken heart» (Memoir, 1915, p. 7).

A grudging obituary in the Times newspaper regarded him as a failure, who had never adjusted to the patterns of the House of Commons:

He never caught the ear of that assembly and was an ineffective leader of the independent group which owed its existence in great measure to his unflagging energy. He... did not at any time gain the complete confidence of the working class. The Labour Party disappointed his hopes. (McLean, 1975, p. 159)

Within the Independent Labour Party a certain element of deification very quickly appeared. Bruce Glasier wrote,

Keir Hardie was the greatest agitator of his day. He stood in many respects unprecedented as a working-class leader in our country. He was the first man from the midst of the working-class who completely understood them, completely sympathised with them, completely realised their plight, and completely championed them. He was the first working-man who fought his way to Parliament for them with no badge but that of Labour and Socialism on his shield. He was the first working man who, having entered Parliament, never deserted them, never turned his back on a single principle, which he had proposed, never drifted away from his class in thought, in feeling or in faith. (Glasier, 1919a, p. 2)

Glasier, who had worked with Hardie since the 1880s, was the obvious biographer, but he died in 1920 after a very long illness and the memorial committee appointed William Stewart, one of the journalists on the Labour Leader, to complete the official biography, which appeared in 1921. As Ramsay MacDonald wrote acerbically in the introduction, Stewart approached the task as a "worshipper», although MacDonald himself did much to add to the hagiographical approach: «He will stand for ever as the Moses who led the children of Labour in this country out of bondage», an image that Hardie had 
used of himself as early as 1883 (Reid, 1978, p. 63). «He was a simple man, a strong man, a gritty man,» said MacDonald, who «got more Socialism from Burns than from Marx» (Stewart, 1921, p. xxiii).

In the aftermath of the Great War a good deal of the focus was on Hardie as the pacifist, the campaigner against war and the internationalist. Various short biographical pieces appeared in the 1920s from the ILP. David Lowe's From Pit to Parliament (1923) and Francis Johnson's Keir Hardie's Socialism (1922) emphasised his role in the formation of the Labour Party and his socialism. Both made extensive use of Hardie's own writing in the Labour Leader and in the Merthyr Pioneer. His son-in-law, Emrys Hughes, also began what was a long sustained defence of the memory with a set of extracts from Hardie's own writing. (Hardie, 1927) All of these quote Hardie's own story - oft repeated and claimed as a formative influence - of his experience as a child of 10 in 1866 arriving late for work, his mother ill and with no food in the house, being forced to stand in front of his employer, a baker, who was tucking into breakfast, only to be dismissed for lateness. There is no collection of Hardie papers of any great significance so all accounts of his early life have to depend to a substantial extent on his own versions.

There also emerged the contrast with Ramsay MacDonald:

No doubt if Hardie had been Premier it (1924 Labour Government) would have been defeated sooner but the spirit of the Party would not have been sapped and weakened, and it would have retained its idealism, its independence and its self respect. (Hughes, 1931, p. 14)

A fuller biography appeared in 1935 by the journalist Hamilton Fyfe. This was in the aftermath of 1931 and the split in the Labour Party occasioned by Ramsay MacDonald's defection to a coalition government. Here again the myth was strengthened. Hardie was the man who always stayed true to his principles and always remained the man of the people, unlike MacDonald with his constant search for «respectability» and his attraction to aristocrats like Lady Londonderry (Fyfe, 1935). G.D.H. Cole, writing during the Second World War, saw Hardie's importance in his having devised a specifically British way to socialism:

Hardie was as much a Socialist as Hyndman, and as fully convinced of the necessity of overthrowing the capitalist order; 
but he disbelieved in the possibility of building in Britain an effective class-war party on strictly Marxist lines, and insisted that no Socialist Party worthy of the name could be created unless the Trade Unions could be induced to take part in it. (Cole, 1941, p. 48)

He too liked the sacking story and the cloth cap, which he suggested was deliberately chosen to emphasise Hardie's difference from the ultra-respectable Lib-Lab trade union MPs. There is something of a lacuna in the 1950s and 1960s with the exception of a semi-fictionalised biography, John Cockburn's The Hungry Heart. A Romantic Biography of James Keir Hardie, in 1956. It has the lot: the struggle against poverty, the self education, the cloth cap, the man of unbending principle, the archetypal Scot whose heart was always in Cumnock with his wife and family, but who was driven to work endlessly for the cause. However, soon afterwards, a history of the Labour Representation Committee for the first time revealed details of the MacDonald-Gladstone pact with the Liberals in 1903 and Hardie's role in the secret negotiations which form the background to Labour's success in 1906 (Bealey, 1958, p. 30$31)$.

Not until 1975 do we have the next substantial biography by Iain McLean. This was a time when there was much debate within the Labour Party about the direction its politics should be taking, and McLean was in sympathy with those who in 1981 broke away from Labour to form a short-lived, centrist Social Democratic Party. It also coincided with the rehabilitation of Ramsay MacDonald in the writings of David Marquand, another supporter of the SDP (Marquand, 1977). McLean was concerned to play down the significance of Hardie's socialism. He suggests that his socialism, well into the 1890 s, was not much more than a belief in land nationalisation - «the word had no particular implications about attitudes to industrial organization» (McLean, 1975, p. 20-21). Rather he sees him emerging from a Liberal-Radical position and retaining many of the Liberal-Radical attitudes. His position, he argues, was one of Labourism. It was the first really critical biography, enlarging on Hardie's readiness to discuss pacts with Liberal radicals, to talk about redrawing party lines and creating a progressive alliance. Hardie, he notes, «was sometimes extraordinarily ruthless, to the point of unscrupulousness, when aroused» (McLean, 1975, p. 75). He also rather delicately hinted at «an emotional over involvement with the WSPU». 
It was left to Kenneth Morgan in his biography, coming out in the same year, to take this further. Morgan sees Hardie as bringing a fusion of late 19th century radicalism and socialism, but with the latter coming only gradually. Even as late as 1887 he argues,

Hardie, while something of a collectivist, was far from being a thoroughgoing socialist. Marxism was virtually unknown to him. He had no vision of industrial society beyond the limited world of the Scottish miners. (Morgan, 1975, p. 22)

Before looking at Morgan further, however, we should note Fred Reid's important thesis and eventual book on the young Hardie, which came out at about the same time as Morgan and McLean's work. He, to a much greater extent that the other two, fits Hardie into a Scottish tradition. He made use of the concept of the independent collier, a mythical concept of the collier as independent labour aristocrat, to explain many of Hardie's attitudes. But he has no doubt that by 1887 Hardie was converted to socialism and familiar with much socialist writing thanks to his mentor in Lanarkshire, William Small, and to a lively radical group in Cumnock. His socialist utopia was one of independent craftsmen cooperating - cutting out the middle man - but socialism just the same (Reid, 1978).

Morgan dealt with the cloth cap image of 1892. Far from its being a cloth cap, it was a country gentleman's deer-stalker. The trousers were yellow tweed - with checks on which you could play draughts according to John Burns - the tie was bright red. This was not a typical Scottish working man. This was «a Bohemian, an eccentric» (Morgan, 1975, p. 55). James Mavor, one of his contemporaries in Glasgow, described him as «very fastidious about his dress... Hardie looked like an artist, and indeed in general his point of view was that of an artist». Bruce Glasier noted that «in his manner of dress he had a curious tendency to bizarrerie... he might have been taken for a North Country professor, or perhaps an editor, a literary man or a naturalist» (Glasier, 1919). He liked to be the outsider. The attraction of the unconventional to him also came out in his relationship with Sylvia Pankhurst, which Morgan was the first to write about.

The traditional picture had been of Mrs Hardie, the wife at home in Cumnock, with no great interest in politics and bringing up a family in considerable poverty, and Hardie, the 
devoted family man, who had to sacrifice all this for the cause. It was not quite so. Mrs Hardie claimed after his death that she had on more than one occasion expressed the desire to come to London, but was actively discouraged. She was with him in Merthyr Tydvil at the 1900 election and actually addressed the crowd. Hardie, on the other hand, was not averse to having his own life in Nevills Court, off Fleet Street in London. He seems to have developed passions for the occasional, young Labour woman. Some of his letters of 1893 to Annie Hines, a young Oxfordshire woman, 20 years his junior, survive. He refers to her as «Sparks» and there was clearly a running theme of Hardie as the Knight Errant and she the lady fair he was rescuing from gloom (Morgan, 1975, p. 58). His great passion was for Sylvia Pankhurst, youngest daughter of Mrs Emmeline Pankhurst. Morgan has them having a brief relationship in 1911-1912. A later study of Sylvia suggests that it lasted from around 1905 until his death in 1915. Hardie's interest in women's suffrage long pre-dated this. He had known the Pankhursts since the early 1890s and under the pseudonym of «Lily Bell» he had written pieces in the Labour Leader on the position of women:

Surely it is an utter absurdity to tell a girl that marriage and motherhood are her chief end in life, as men are so fond of doing, and then even to consider the possibility of allowing her to enter upon such duties in ignorance, leaving her to find out from bitter experience whether or not she is fitted to fulfil them... There is too much prudery, too much fear of speaking plain among us. To what depths of degradation has our humanity fallen, when the very means by which this humanity is perpetuated is regarded as unclean, and almost as if it were «of the devil», instead of God. (Stevens, 1987, p. 66)

Sylvia came to London to study art in 1904 when she was 22 and Hardie was 48. She and Hardie probably became romantically involved soon afterwards and she visited him often at Nevills Court. Letters between them survive from 1911, when Sylvia was in the USA, and 1912. The relationship is not hidden. Sylvia writes to «My Angel dear», «darling» and «my dearie» «I don't want anyone but you but I want you so». Hardie writes to his «Little Sweetheart» and recalls «the pressure of my arms around you» (Stevens, 1987, p. 112). Fenner Brockway recalls once seeing Sylvia sitting on Hardie's knee (Brockway, 1977, p. 22). 
By this time, the great complaint of his colleagues in the Labour Party was that he showed little interest in anything but women's suffrage and he was more accessible to the suffragettes than to trade unionists. He was prepared to go with the Women's Social and Political Union in pressing for only limited suffrage to get at least some women the vote, rather than the complete reform to bring universal suffrage which the party was demanding. As MacDonald later noted, «he sorely tried the loyalty of our own women by going out of his way to greet those who had done everything in their power to harass and insult them» (Stewart, 1921, p. xxiii). Caroline Benn suggests that by 1912 «Sylvia was becoming tiring and Hardie escaped whenever possible to do what he really loved, his "open air" work» (Benn, 1992, p. 322). When he died Sylvia wrote movingly of him in The Woman's Dreadnought of his «deep-set eyes like sunshine distilled, as we see it through the waters of a pool in the brown earth».

In the 1980s Hardie was taken up by the Moral Rearmament Movement as a religious socialist in contrast to atheistical socialism, with a play by Henry MacNicol, The Man they could not buy, and as Christian Socialism has regained influence in the ranks of the recent Labour Governments so Christianity's importance for Hardie has been emphasised (Dale, 2000, p. 2638). The most recent substantial biography was by Caroline Benn in 1992. If one can get behind some of the factual errors and misunderstandings of Scotland in the volume, there are some new and quite interesting things in it. She has a great deal on the family and shows much empathy for a family that had to play second fiddle to the political demands (Benn, 1992).

The saintly Hardie still remains in the myths of the Labour Movement, still a name to be contrasted with the pragmatism of New Labour. But a more realistic portrait has now emerged. Whatever he was, he was not the Scottish working man incarnate. He was a one off, but that is not to say that his Scottishness was not important and he ensured that home rule for Scotland became part of the Party's programme. His socialism was about creating a new type of person and a new society, not about solving industrial problems - «a blinding vision of a new society, in which man would be purified and re-incarnated and mundane human relationships superseded», according to Morgan (Morgan, 1975, p. 45). He was intolerant of the poorest who were somehow not seen to be trying to improve 
themselves. As Fred Reid says, he tended to despise the poorest for a lack of moral discipline and was attracted by the idea of home colonies to generate that moral discipline (Reid, 1978, p. 180). In Hardie's fullest statement of his credo, From Serfdom to Socialism, he wrote, «Socialism is much more than either a political creed or an economic dogma. It presents to the modern world a new conception of society and a new basis upon which to build up the life of the individual and the state» (Hughes, 1956, p. 143). Philip Snowden, on the other hand, makes the point that «though he (Hardie) repudiated the dogma of the "class war", his appeal was invariably to the workers as a class» (Hughes, 1956, p 220). Although Hardie separated himself from formal, organised religion and wrote against what he called «churchianity», (Benn, 1992, p. 106) he never lost his evangelical fervour. Hyndman wrote of Hardie's «queer jumble of Asiatic mysticism and supernatural juggling... called Christianity» and Hardie's closest friend was the Salvation Army officer, Frank Smith. The busts that adorned his room in Nevills Court were those of Ralph Waldo Emerson and Walt Whitman, although there was a portrait of Marx. But this mixture of Christianity, transcendentalism and socialist theorising was the world of Scottish socialism in the 1880s when Hardie was discovering it. It was not about trade unionism and the ownership of industry: "It is not by talking economics that the world will be made better» (Lowe, 1923, p.104). It was about a personal transformation.

There is no doubt that he was not an easy person. Mary MacArthur, at his funeral, pointed out that he was a «very lonely man... and that he had very few real cronies». His journalist colleague, Lowe, wrote of him as «a difficult man, reticent». At the same time, he had considerable vanity, as came out in his appearance and his treatment of colleagues. He had the evangelical's sense of an inner voice «and only when he was propelled by it was he assured that his work would prevail» (Glasier, 1919, p. 63). But he also could be devious, «an overcunning Scot whose demagogic artfulness one cannot trust», according to Engels (Morgan, 1975, p.71). There were others who came to dislike him intensely. As early as $1893 \mathrm{Mrs}$ Webb, who regarded him as «vain and egotistical», noted in her diary that John Burns's «hatred of Keir Hardie reaches about the dimensions of mania»(Webb, 1982, 12 October 1893). At a later stage Burns told Hardie to his face that «he would be 
known as a leader who never won a strike, never organised a Union, governed a parish, or passed a Bill» (Morgan, 1975, p. 277). MacDonald often accused him of vanity and showmanship and a refusal to consult colleagues (Marquand, 1977, p. 108). Robert Blatchford never liked him. Even in old age he declared that Hardie has "neither brains nor guts" (Benn, 1992, p. 135).

Hardie was much more an opportunist ready to trim and adjust and collaborate with non socialists than was once admitted. To quote Morgan, «He persistently advocated shortterm agreements in pursuit of minimalist goals » (Morgan, 1975, p.135). In his limited theorising he is not so different from MacDonald or even from the Fabians in seeing socialism coming gradually:

That Socialism is revolutionary is not in dispute, but that it can only be won by violent outbreak is in no sense true... I can imagine one reform after another being won until in the end Socialism itself causes no more excitement than did the extinction of landlordism in Ireland a year ago. (Hardie, 1927, p. 121)

Morgan makes the point that the problem in Hardie and MacDonald's relationship was that they were too alike in temperament, «both solitary brooders» (Morgan, 1992, p. 142). The difference was that Hardie was almost incapable of compromising with others, not in theory but in practice. He was clearly driven by some inner vision and inner resolve, a sense of mission, to create a mass working-class party that would actually achieve power, not just be on the fringes of it, but he lacked the temperament to build it. Philip Snowden probably got him about right.

He was the unsparing iconoclast who sought to break the illusions and conventions of his generation. He had set himself an ideal which he pursued regardless of the hostility and opposition of enemies and often with scant regard for the criticism and advice of his friends. (Hughes, 1956, p. 3)

Nonetheless Hardie's belief that socialism has to be about the transformation of the individual as well as of society continues to inspire many and the myth remains powerful. 


\section{Bibliography}

Bealey F. and Pelling H., Labour and Politics 1900-1906: A History of the Labour Representation Committee, London, 1958.

Benn C., Keir Hardie, London, 1992.

Brockway F., Towards Tomorrow, London, 1977.

Cole G.D.H., James Keir Hardie, Fabian Society Biographical Series, 1941.

Dale G., God's Politicians. The Christian Contribution to 100 Years of Labour, London, 2000.

Davies A. J., To Build a New Jerusalem. The British Labour Movement from the 1880s to the 1990s, London, 1992.

Fyfe H., Keir Hardie, London, 1935.

Glasier J. B., James Keir Hardie. A Memorial, Manchester, 1919.

-, Keir Hardie: The Man and His Message, London, 1919a.

Hardie J.K., Speeches and Writings from 1808 to 1915, Emrys H. ed., Glasgow, 1927.

Harrison B., Drink and the Victorians. The Temperance Question in England 1815-1872, London, 1971.

Holroyd M., Bernard Shaw. The Pursuit of Power, London, 1989.

Hughes E., Keir Hardie. Some Memories, London, 1931.

-, Keir Hardie, London, 1956.

Johnson F., Keir Hardie's Socialism, London, 1922.

Lowe D., From Pit to Parliament. The Story of the Early Life of James Keir Hardie, London, 1923.

Marquand D., Ramsay Macdonald, London, 1977.

McLean I., Keir Hardie, London, 1975.

Memoir of James Keir Hardie MP and Tributes to his work by Robert Smillie, J. Ramsay Macdonald MP and Mary MacArthur, Glasgow, 1915.

Morgan K.O., Keir Hardie. Radical and Socialist, London, 1975.

-, «Britain's Vietnam? Lloyd George, Keir Hardie and the Importance of the "Pro-Boers" ", in W.R. Louis ed., Still More Adventures with Britannia, London, 2003.

Reid F., Keir Hardie. The Making of a Socialist, London, 1978.

Stevens C., "A Suffragette and a man; Sylvia Pankhurst's personal and political relationship with Keir Hardie, 18921915», Ph.D. thesis, University of Rochester, 1987.

Stewart W., J. Keir Hardie. A Biography, London, 1921.

Webb B., The Diary of Beatrice Webb, N. and J. MacKenzie eds., London, 1982. 